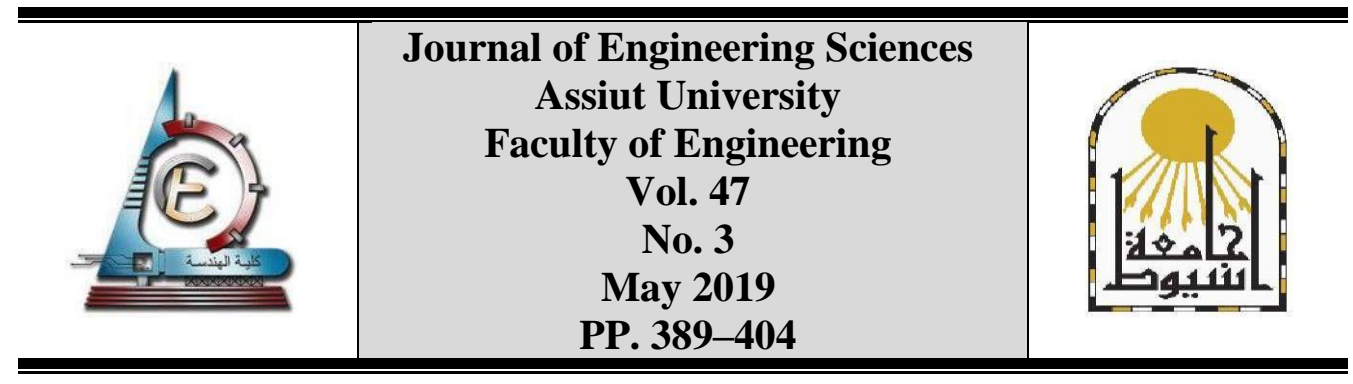

\title{
TOWARDS A BETTER PERFORMANCE IN OFFICE BUILDINGS BY INTEGRATING NATURAL ELEMENTS
}

\author{
Ahmed Abd Elghany Morsy ${ }^{1}$, Mahmoud Abdelrahman Moustafa Emam ${ }^{2}$ \\ ${ }^{1}$ Faculty of Fine arts, Helwan University \\ ${ }^{2}$ Architect LEED AP BD+C.
}

Received 8 January 2019; Accepted 13 February 2019

\begin{abstract}
The fast rhythm of today's economic environment imposes the full potential of the workforce and no longer affords to waste any. There are many factors in the workplace environment that influence the performance of the occupants. Workplace design plays a major part as one of these factors. Meanwhile, recent studies have shown a positive correlation between nature, the built environment and human performance. On average, people spend ninety percent of their time in artificial built environments and man-made environments that weaken the opportunity for humans to connect with their natural environment. The outcome of this study is intended to provide insight into the perception of natural elements design in the context of urban office buildings' environment and a greater understanding of how integrating these elements into workplace environments could renew a historically innate human connectedness to the natural environment that support occupants' productivity, and therefore their overall health and well-being.
\end{abstract}

Keywords: Workplace design, Office Buildings, Nature Integration, Biophilic Design, human connection, Occupants productivity, and Occupants wellbeing.

\section{Introduction}

The relationship between the workplace environment design and the productivity of building occupants is complex and still not fully understood. Local customs and expectations, occupants' activities, and the building's site, design, and construction are just a few of the variables that make it difficult to quantify and measure the direct effect of a building on its occupants.

Researches linking engagement with the workplace environment to the performance and occupants' satisfaction has now begun to emerge. Although further research is required, the published studies suggest a positive correlation between engagement with the surrounding environment and occupants' performance. A high-quality working environment seems likely to contribute to an engaged, and hence, productive workforce. In the same way, a poor-quality working environment is likely to be a detracting factor from an engaged workforce.

The interconnectedness between human beings and nature illustrates a theory that human evolution has been dependent on the natural environment for a sense of overall well-being and personal fulfillment since the beginning of mankind [1] As the world 
population continues to grow, connecting to nature become even more important as it was. Design that reconnects us with nature is essential for providing people opportunities to live and work in healthy places and spaces with less stress, which lead to productivity increasing and greater overall well-being.

Modern artificial environments have weakened the connection between the humans and their natural environment. This connectedness however could be strengthened by the design industry, as design possesses [3]. The ability to promote this relationship through built environment solutions and encouraging the connection between the occupants and natural elements in their physical work environment supposedly affect their performance positively and therefore their overall well-being [4].

The gap that continues to expand nowadays because of modernity, led to the appearances of new terms such as 'Biophilic Design' 'Biomimicry' 'Green Architecture. That help the building's users by re-establishing the nature-human being mutual relationship.

After investigating the related literature, it can be concluded that integrating natural elements in the office buildings design has effect on occupants' behavioral aspects [3]. This Behavioral Simulation process is the main approach of this research which is a step towards demonstrating how natural elements can affect occupants' performance, and therefore overall well-being in office buildings [3]. The research study excluded the examination of natural elements integration in any other environment rather than office buildings.

Some people could say that the design of an office has a material impact on occupants' productivity and performance sound obvious and goes without saying. However, it does need saying, loud and clear, because this evidence is not yet translating at scale into design and financing decisions. Some practices will be highlighted and documented in this paper. The knowledge established would be helpful for researchers, designer, and engineers. This paper will also be of benefit to researchers who endeavor to undertake research in this area and could act as a starting point.

\section{Research problem}

A range of outdoor and indoor factors such as thermal, visual, acoustic, furniture, and natural elements presence, can impact the performance of the occupants. These relationships could often be very complicated and can have both short-term and long-term impacts on occupant's well-being. Issues such as sick building syndrome (where no disease or cause can be identified) yet acute health effects are linked to time spent in a building, and pollutants have an impact on the occupants' performance in office buildings [34]. Studies also linked mental health and illnesses that are not easily noticeable in the short term could be major problems in the long term [34].

Poor indoor environmental quality is an impediment to occupant perception and overall satisfaction with office buildings [2]. Factors that are characterized by such ability to show acceptable values could be divided into factors that:

- Directly affecting IEQ such as indoor temperature, relative humidity, air quality.

- Affecting perception and satisfaction with the overall indoor environment, such as lighting, noise, furniture, natural elements presence and psychological discomfort.

Focusing on the presence of natural elements, this issue is important in a world where we become more and more disconnected to nature. We do use the nature and we are draining its resources, and due to urbanization and modern lifestyle, great amount of 
people work quite separated from it. Nature has appreciated values that the built environment doesn't have, what if these values could be transformed into the office buildings built environment in Egypt? Can we use nature to create a better environment for office buildings' occupants and affect their productivity?

\section{Research hypothesis}

The connectedness between people and their natural surroundings is one examined and elaborated on by the design industry, as design can promote this relationship through built environment solutions that encourage the connection between people and natural elements. In contrast, environments that have been designed with the failure to maintain a healthy relationship between the user and their natural surrounding elements have restrained this essential connectedness which has hindered employees' performance.

\section{Importance of research}

Most post occupancy evaluations' studies of green buildings have focused on more easily quantifiable criteria such as energy use and physical measurements of environmental conditions [37]. Still, studies are needed to clarify how buildings are affecting its occupants [36]. There is, consequently, a need to evaluate occupants' perception to begin to understand the impact of workplace physical environment on the occupants in the widest sense [36]. The evaluation of occupant perception and satisfaction forms a significant aspect of probing the natural elements within the workplace. In building researches, perception evaluation is a means to understanding the forces that drive occupants' needs and enables facilities managers also make decisions and improvements to meet those needs [36].

\section{Objective of the research}

This paper will try to document how employees' performance and productivity are affected by natural elements integration within the space. Given that we spend more than $90 \%$ of our life indoors (The National Human Activity Pattern Survey), it is important to understand it and act accordingly. Green building designs don't automatically guarantee that the building designed will be comfortable and enhance employees' performance or ensure occupant well-being.

The research paper would seek to understand the relationship between employees' performance and their physical work environment, and to analyze the influence of natural elements integration with office building design on occupants' in Egypt.

\section{Research methodology}

Quantitative research work with both Inductive and Deductive approach. The inductive approach, through the data gathering, arrangement and analyzing information, while the Deductive approach is to sum up all the analyzed data and case studies to be presented in a general summary, results, discussion and a conclusion.

To understand the relationship between integrated natural elements with the office buildings' design and its effect on occupants, Analytical study will be carried out to endorse or approve the guidelines with four office buildings with different occupancy profession as a sample.

A questionnaire will be used to collect primary data and observation will be used to collect information about how integration between natural elements and the office building design affect occupants. The questionnaire will use a five point Likert scale to measure all the variables. The scale varies from 1 (strongly disagree) to 5 (strongly agree) for most of 
the questions. The statistical techniques will be used to analyze the employees' response towards the workplace design and its impact on their performance.

\section{Research limitations}

The research study excluded the examination of natural elements integration with design in any other environment than the office building design scope and how it affects the employees' productivity and the overall performance.

\section{Humans and nature}

During the last century, research has been increasingly drawn toward understanding the human nature relationship and has revealed many ways humans are linked with the natural environment. Some examples of these include humans' preference for scenes dominated by natural elements, and benefits associated with engaging with nature. Mentally, we can become disconnected from nature because we're now deeply embedded in a human-made world [3].

Nature can be found in the earliest human buildings. The Egyptian sphinx, or the acanthus leaves in the Greek temples as shown in (figure 1,2) or even at the hanging gardens of Babylon. Representations of animals and plants as well have been used for decorative in many civilizations. Cultures around the world have brought nature into homes and public spaces.

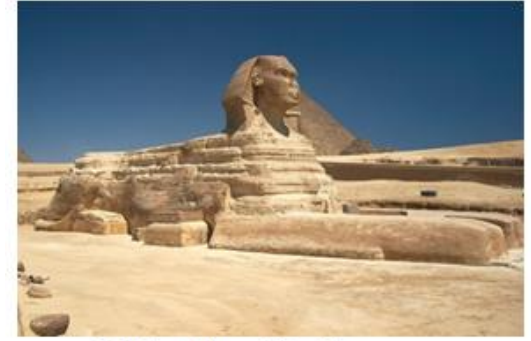

Fig. 1. Great Sphinx of Giza, Giza.

Source: National Geographic image collection.

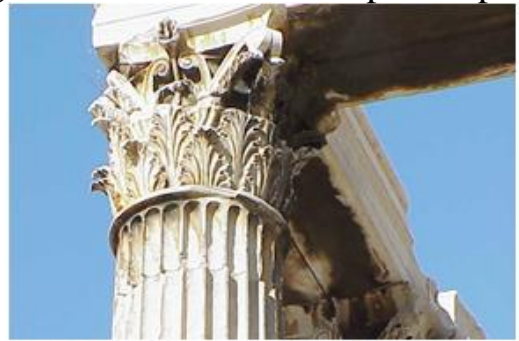

Fig, 2. Corinthian column, Temple of Olympian Zeus, Athens. Source: Steven Zucker, khan academy.

Prior to and even after the industrial revolution, most of artists pushed back against buildings that reflected the industries cities as they drew from nature for inspiration [4].

In the mid-19th Century; winter gardens and conservatories become requisites of wealthy houses in most all around the world [5]. The biomorphic natural forms of Antonio Gaudís buildings remain strong examples of this period which could be shown in his most famous building segrada familia as shown in (figure 3). Also, louis sullivan created elaborate ornamentation with leaves found in nature and cornices that represent tree branches as built in his guaranty building in buffalo as shown in (figure 4), while Frank Lloyd Wright abstracted prairie flowers and plants for his art glass windows. Wright also used the grain of wood and texture of brick and stone as a decorative element in his famous falling-water house as shown in (figure 5).

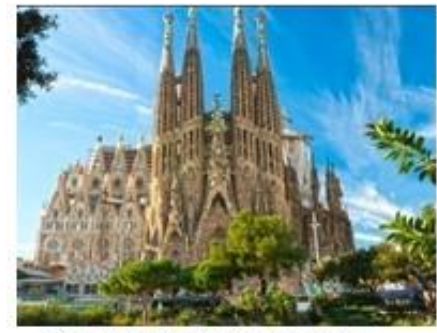

Fig. 3. Sagrada Familia, Barcelong Source:Rennie Jones, Archdrily.com.

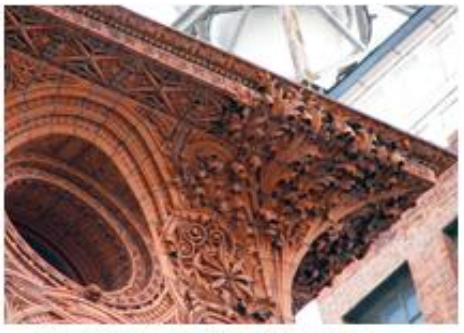

Fig. 4. Guaranty Building, New York. Source: Robert Kirkham/Buffalo News.

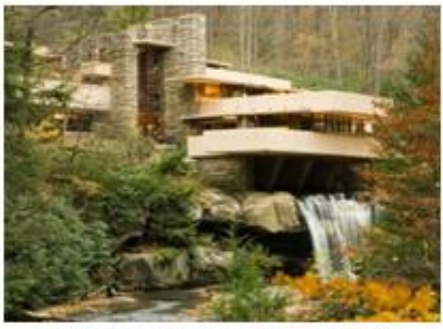

Fig, 5. Falling-water house, Pernsylvania Source: Adelyn Perez, Archdaily.com. 
In contemporary architecture, there are much ornamentation stripped from the buildings, but, like Wright, designers used wood grain and the veining of stone as decorative elements and were equally concerned with exploring the relationship of interior to exterior. Nature seems to have qualities that today can be regarded as lacking in the built environment surroundings human beings. That's why a lot of phrases and movements came to surface these past few decades such as, Green Architecture, Biomimicry or Biomimetic design, and Biophilic design.

Biomimicry in architecture is a contemporary philosophy of architecture that seeks solutions by understanding the rules governing the natural forms. It is an approach to sustainable design that follows a set of principles and It is considered as a part of a larger movement known as biomimicry, which is the examination of nature and its models, systems, and processes for the purpose of gaining inspiration to solve expected man-made problems [35]. For example the lotus temple in India or the art museum in Milwaukee as shown in (figure 6, 8).

It is the practice of designing buildings and products that simulate processes which occur in nature at any phases of its phases. Designers will benefit from studying certain aspects of nature a good example of this will be the Eden project as shown in (figure 7). As buildings may face some problems that need solutions, it may be in nature that architects can find the answers. It also considers as one of the strategies of the biophilic design.

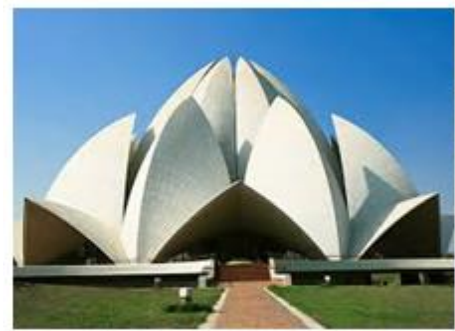

Fig. 6. Lotus Temple, Delhi. Source: jedi-master, britannica articles.

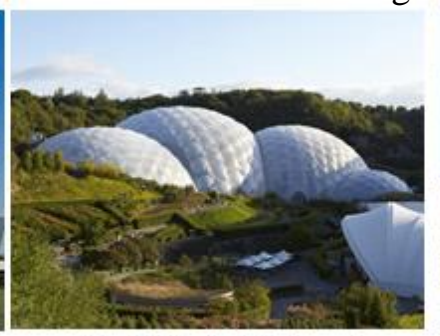

Fig. 7. Eden Project, Cornwall. Source: The guardian articles.

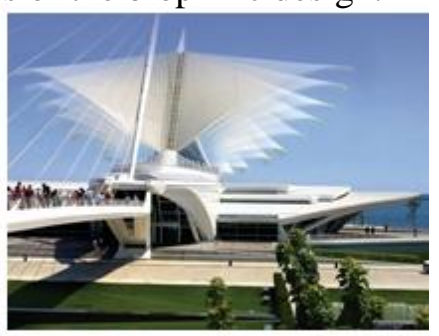

Fig. 8. Art Museum, Milwaukee. Source: Calatrava.com projects.

As for the green architecture, the United States Green Building Council defines green buildings as ones that have significantly reduced or eliminated negative impacts on the environment. While it has brought green design and construction practices into the mainstream, systematic assessments of how these buildings affect the occupants are rarely done [27]. In building researches, perception evaluation is a means to understanding the forces that drive occupants' needs and enables facilities managers also make decisions and improvements to meet those needs [36].

A new movement related to green architecture 'biophilic design' has recently gained much momentum within the building community. The leading opinions are that we should bring as much of nature as we can into our everyday environments. While the green movement has often focused on the means, biophilic design tends toward emphasizing the end results, establishing natural-based habitats for humans to live and work. Biophilic design incorporates elements derived from nature to maximize human functioning and health [7].

The term "bio - philia" means "the love of life". It was used by Fromm to describe a psychological orientation of being attracted to all that is alive [6]. Although named by Fromm, the concept of biophilia has been proposed and defined many times over. Biophilia as a term was popularized later by biologist Edward Wilson in in his book. He defines biophilia as "the urge to affiliate with other forms of life". Biophilia implies that we are nature-loving because we are of nature; our brains, our bodies evolved in nature and as biological beings we need it to sustain our physical and emotional health [7]. 
The Biophilia Hypothesis suggests that humans have an instinctive bond with nature and that people tend to show a positive response when they experience a connection with nature [7].

Biophilic architecture is based on this hypothesis, that humans have an innate connection with nature that should be expressed in their daily lives, especially in cities. Biophilic design means that the building could begin to contribute to the environment and become a part of the ecosystem instead of only decreasing its damage. Connection to nature on a daily basis reinforces the values of respect and care for the environment that are necessities for sustainable communities [8].

\section{Relationship between nature and productivity}

With the emergence of the green building movement in the early 1990s, linkages were made between improved environmental quality and worker productivity. While the financial gains due to productivity improvements were considered significant, productivity was identified as a placeholder for health and well-being, which have even broader impact [9].

Environmental psychology researches assume that being connected to nature is an adaptive human function that assists with psychological restoration. Which means that within an urbanized environment bringing in elements that allow direct nature connection or indirect connections (i.e., interior design using natural elements, indoor plants or views of greenery) can help us to mentally recover and provide respite from our day to day activities and to increase occupants' performance 10? A brief of some strategies were natural elements is integrated within office buildings could be given as the following

\subsection{Visual connection with nature}

Building occupants who can visually connect with outdoor environments while performing everyday tasks experience greater satisfaction, attentiveness, and productivity. Outside views that incorporate natural elements are more enticing and offer better visual respite. Workers seated at computers, who often develop eye strain or dry eyes from looking at their screens for extended periods without a break, find relief in attractive distance views [11]. The New York Times building provides a good example of connecting indoor workspace and the nature by providing an indoor garden as shown in (figure 9).

Visual comfort is very important for productivity of the occupants in buildings [12]. The correlation between views and satisfaction in offices has been described in several articles; a sketch has been made by Viktoria in her research to imagine the greenery office spaces as shown in (figure 10). For instance, Kaplan found in a study that office employees with views of only built components had higher levels of job stress and lower levels of satisfaction than those with views of natural elements [13]. A few trees, some landscaping or some signs of vegetation seems be enough to make a difference regarding stress and satisfaction [14].

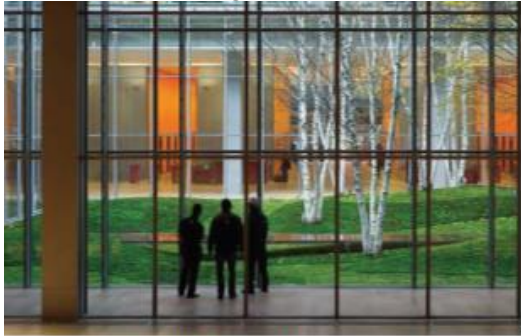

Fig. 9. The NY Times Building, New York. Source: HMWhite, architectmagazine.com.

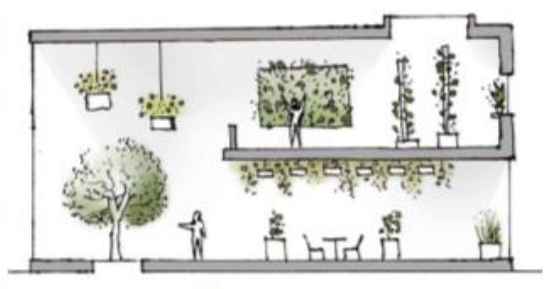

Fig. 10. Indoor greenery Sketch Source: Viktoria, E., thesis 2015. 
Stress recovery from visual connections with nature have reportedly been realized through lowered blood pressure and heart rate; reduced anger, and aggression; improved mental engagement, attitude and overall happiness [15]. In another study Stigsdotter confirms the importance of views of nature. The study shows value of having the opportunity to take a break outdoors [16]. It is believed that there is a relationship between accesses to green outdoor areas at the workspace influence the level of stress as shown in (table 1).

Table 1.

Effect of access to green outdoor areas at the workspace, Stigsdotter [16].

\begin{tabular}{|l|l|}
\hline \multicolumn{1}{|c|}{ Access to green outdoor areas } & \multicolumn{1}{|c|}{ Stress occasions per person / year } \\
\hline Having no view of a garden and no chance to go out during breaks. & 153.73 \\
\hline $\begin{array}{l}\text { Having no view of a garden and a chance of a break } \\
\text { outdoors (once a month at most). }\end{array}$ & 104.08 \\
\hline $\begin{array}{l}\text { Having a view of a garden and few or no chances of a } \\
\text { break outdoors (once a week at most). }\end{array}$ & 94.66 \\
\hline $\begin{array}{l}\text { Having a view of a green garden and chances of a break in } \\
\text { a green garden (more than once a week). }\end{array}$ & 77.07 \\
\hline
\end{tabular}

Achieve a direct line of sight to the outdoors via vision glazing, noting that the view glazing in the contributing area must provide a clear image of the exterior, not obstructed by frits, fibers, patterned glazing, or added tints that distort color balance [17].

\subsection{Non-visual connection with nature}

Auditory, olfactory, or haptic that engenders a positive reference to nature, living systems or natural processes that considers familiar and comfortable, whereby sounds, aromas, and textures are reminiscent of being outdoors in nature. Natural sounds reduce cognitive fatigue and helps motivation and concentration [18]. Participants of one study who either listened to river sounds or saw a nature movie with river sounds during a post-task restoration period reported having more energy and greater motivation after the restoration period compared to participants who only listened to office noise or silence [18]. The act of touching real plant life has shown to enhance our overall well-being which reflects on occupant's productivity by inducing relaxation through a change in cerebral blood flow rates [19].

\subsection{Exposure to water elements}

The effective use of water as a design feature is complex, and often contingent on such considerations as perceptions of quality, quantity, movement, clarity, and other characteristics [20].

According to Kellert, Heerwagen and Mador, water plays an important role in our everyday life enhancing human beings' existence. Water could provide thermal comfort in the summer and break the heat waves on the surrounding environment [21]. Visual preference research indicates that a preferred view contains bodies of clean water [22]. Not only visually exposed to water that helps also auditory access and perceived or potential tactile access to water reportedly reduces stress [23].

\subsection{Daylight interaction}

Daylight is consistently identified as an important and preferred feature by most people in the built environment. People depend on visual acuity to satisfy various physical, emotional, and intellectual needs [3]. Loftness and Frumkin note studies showing that 
natural light is both physically and psychologically rewarding to people, frequently contributing to their health, productivity, and wellbeing in the built environment [24].

The impact of daylight on performance has been studied for many years, researches showed that productivity is higher in good day lighted work places, the research focus was on lighting strategy and task performance [25]. Access to sufficient daylight has been shown to increase productivity in the workplace as shown in (figure 11). The presence of daylight and windows, as well as opportunities for active and passive contact with natural light, sensory change and variability, positively also impact occupants' well-being [25]. A good example could be the living planet centre as shown in (figure 12). Disruption of these rhythms can lead to lack of performance and long-term health care problems, including mental disorders [3].
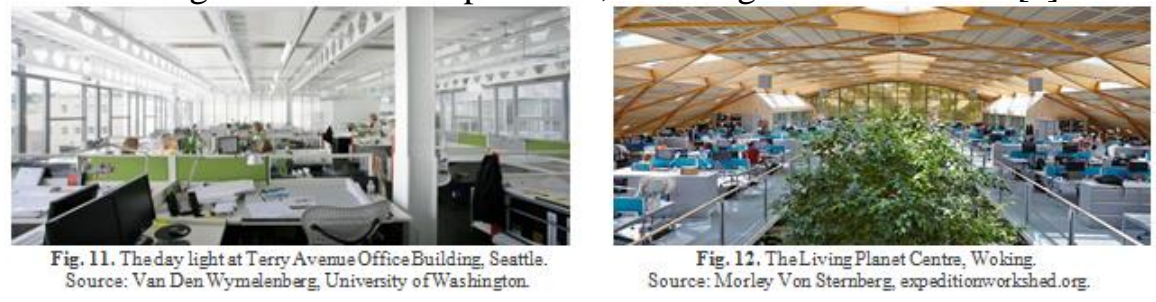

\subsection{Thermal and airflow variability}

A large body of laboratory and field research has demonstrated how thermal conditions inside buildings directly affect people's satisfaction and performance. People prefer natural ventilation over processed and stagnant air. Important conditions include quality, movement, flow, stimulation of other senses such as feel and smell [26]. Changes in air temperature, relative humidity, airflow across the skin, give the feeling of refreshing, active, alive, invigorating and comfortable [13].

Researches measure the effects of natural ventilation, resulting thermal variability, that affect positively worker comfort, and productivity. Researches also shows that people like moderate levels of sensory variability in the environment, including variation in light and temperature, and that an environment devoid of sensory stimulation and variability can lead to boredom and passivity [27].

\subsection{Natural materials}

People generally prefer natural over artificial materials. A space with natural materials feels rich, warm and authentic and affects occupants' productivity and overall performance. In a series of experiments examining the effect of the presence of natural materials in a space on the psychological functioning of participants. Results concluded that this kind of exposure before conducting a task facilitates the performance [28].

Researches about how nature in form of material, like wood, affects people, a study by Tsunetsugu, Miyazaki and Sato indicates that rooms with wooden finish decreases the blood pressure and improves the perceived comfort and therefore occupants' performance [29].

\subsection{Natural shapes and forms}

People have been enhancing living spaces with portrayals of nature since time immemorial, and architects have long made spaces utilizing components inspired by trees, bones, wings and seashells [3]. Many classic building ornaments are derived from natural forms, and countless fabric patterns are based on leaves, flowers, and animal skins. 
Contemporary architecture and design have presented more organic building forms with gentler edges or even biomimetic characteristics [1] (Figures 13 and 14).

Natural forms and patterns strategy has evolved from research on view preferences, reduced stress due to induced shift in focus, and enhanced concentration and occupants' overall performance [30]. While our brain knows that biomorphic forms and patterns are not living things, we may describe them as symbolic representations of life [31].

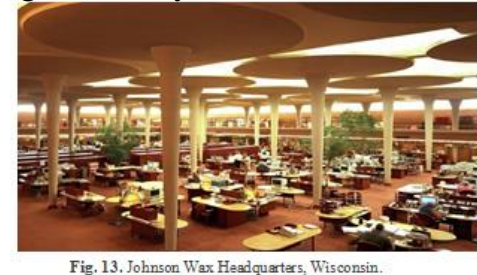

Fig. 13. Johnson Wax Headquarters, Wiscon
Source: Kelly Minner, Archdaly com

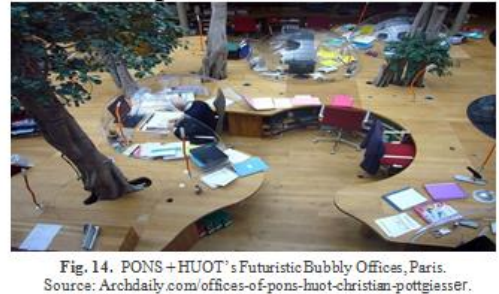

Source: Archdaily, com offices-of-pons-huot-christien-potteiesser.

\section{Design Considerations and Integration}

Increasingly dense urban environments, coupled with rising land values, elevate the importance of natural design across a spatial continuum from new and even existing buildings. Each context supports a platform for myriad opportunities for integrative natural design, and mainstreaming healthy building practices for occupants and for society. There are some factors that we should take in consideration while planning to integrate the building with natural elements some of them are the following:

- Identifying the desired responses and outcomes from the integration

- Design strategies and interventions

- Quality and Quantity of intervention

- $\quad$ Locally Appropriate Design

- Scale and feasibility
- Diversity of design strategies

- Duration of exposure

- Climate and ecology

- Culture and demographics

Developing an early strategy in a project will help ensure cost-effective opportunities are not lost before they are fully considered. The integration of natural elements within the workplace strategy in the early stages of development will put team members on equal footing and allow for the identification of potential strengths, challenges and opportunities. However, for a successful integration we should consider the following:

- Environmental quality.

- Controlling for effectiveness.
- Multi-platform solutions.

- Tracking and measuring efficacy.

\section{Analytical studies}

Deducing and deriving the guidelines of natural elements integration with office building design from the literature reviews not adequate. However, analyzing examples that used similar strategies within office buildings design was intended to further authenticate these elements. The followings aim at providing a revalidation to the deduced guidelines through analyzing examples of office buildings facilities that integrate natural elements in their design.

The following (table 2) will present some of the international and local case studies that used some of integrating natural elements into built environment strategies and its effect on the occupants. 
Table 2.

General Information about the selected case studies internationally and locally.

\begin{tabular}{|c|c|c|c|c|}
\hline & Location & Project Type & $\begin{array}{c}\text { Year of } \\
\text { Completion }\end{array}$ & Design Team \\
\hline \multicolumn{5}{|l|}{ International Case Studies } \\
\hline $\begin{array}{l}\text { Kickstarter ' Commercial } \\
\text { Headquarters' }\end{array}$ & $\begin{array}{l}\text { New York, } \\
\text { USA }\end{array}$ & $\begin{array}{l}\text { Headquarters of } \\
\text { public benefit } \\
\text { corporation }\end{array}$ & 2014 & Ole Sondresen Architect \\
\hline Cookfox architecture studio & $\begin{array}{l}\text { New York, } \\
\text { USA }\end{array}$ & Architecture Studio & 2006 & Coolffox Architects LLP \\
\hline \multicolumn{5}{|l|}{ Local Case Studies } \\
\hline $\begin{array}{l}\text { Office building functioning as } \\
\text { an architectural company (A) }\end{array}$ & Giza, Egypt & Architecture company & 2014 & Perkins + Will \\
\hline $\begin{array}{l}\text { Office building functioning as } \\
\text { a Bank (B) }\end{array}$ & $\begin{array}{c}\text { New Cairo, } \\
\text { Egypt }\end{array}$ & Bank & 2014 & $\begin{array}{c}\text { Enginaering Consultants Group } \\
\text { (ECG) }\end{array}$ \\
\hline
\end{tabular}

Meanwhile (table 3) will present the strategies used in each building and how it affected the occupants and the employees of each building.

Table 3.

The natural element strategies that were used in the selected case studies internationally and locally.

\begin{tabular}{|c|c|c|c|}
\hline & General Description & Used Strategies & Outcomes \\
\hline \multicolumn{4}{|l|}{ International Case Studies } \\
\hline $\begin{array}{l}\text { Kickstarter ' } \\
\text { Commercial } \\
\text { Headquarters' }\end{array}$ & $\begin{array}{l}\text { - With floor to ceiling curtain walls which } \\
\text { walls allow occupants to experience the } \\
\text { landscape from their dests and common } \\
\text { spaces. } \\
\text { Natural materials play an important role } \\
\text { in the structural elements and design } \\
\text { finishes of the building. It reflects the } \\
\text { local ecology and geology, cresting a } \\
\text { distinct sense of place. }\end{array}$ & $\begin{array}{ll}\text { - } & \text { Visual Connection } \\
\text { With Nature. } \\
\text { - } \quad \text { Daylight } \\
\text { interaction. } \\
\text { - Non-Visual } \\
\text { Connection with } \\
\text { Nature. } \\
\text { - Natural Materials. }\end{array}$ & $\begin{array}{l}\text { - Research shows that the used } \\
\text { strategies forcormecting with nature, } \\
\text { increase concentration, attention, } \\
\text { reduce stress, boredom, and improved } \\
\text { comfort therefore increase the } \\
\text { employees to bemore productive and } \\
\text { innovative. Whilematerial comection } \\
\text { with nature decreased diastolic blood } \\
\text { pressure, improved creative } \\
\text { performance }\end{array}$ \\
\hline $\begin{array}{l}\text { Cookfox architecture } \\
\text { studio }\end{array}$ & 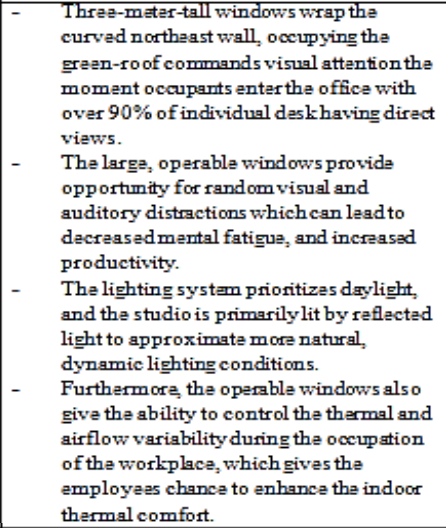 & $\begin{array}{l}\text { - Visual Connection } \\
\text { With Nature. } \\
\text { - Daylight } \\
\text { interaction. } \\
\text { - Thermal and } \\
\text { airflow variability. } \\
\text { - Natural shapes and } \\
\text { forms. }\end{array}$ & $\begin{array}{l}\text { - The results reveal a strong relation } \\
\text { revealed between lack of visual } \\
\text { connection withnature and increased } \\
\text { reported levels of stress. Thermal } \\
\text { airflow variability has been shown to } \\
\text { increase comfort, prochuctivity, } \\
\text { improve concentration, and improve } \\
\text { perception of temporsl and spatial } \\
\text { plessure, all areas within proximity to } \\
\text { operable windows show positive } \\
\text { levels of thermal satisfaction }{ }^{33} \text {. }\end{array}$ \\
\hline \multicolumn{4}{|l|}{ Local Case Studies } \\
\hline $\begin{array}{l}\text { Office building } \\
\text { functioning as an } \\
\text { architectural company } \\
\text { (A) }\end{array}$ & $\begin{array}{l}\text { - With the three curtain wall facades, } 90 \% \\
\text { of the employees in the six floors building } \\
\text { have a direct connection with the outdoor } \\
\text { environment. } \\
\text { The orientation of the building andits } \\
\text { shape promote benefits of daylight. } \\
\text { The building's interior entrancevertical } \\
\text { shading sys tem inthe atrium was inspired } \\
\text { by the Egyptian blue lotus native to } \\
\text { Egypt. } \\
\text { A presence of water is foumdin the main } \\
\text { entrance, a designed watertrough } \\
\text { alongside the main corridors andunder } \\
\text { the shading system }\end{array}$ & $\begin{array}{l}\text { - Visual Connection } \\
\text { With Nature. } \\
\text { - Natural shapas and } \\
\text { forms. } \\
\text { - Exposure to water } \\
\text { elements. } \\
\text { - Daylight } \\
\text { interaction. }\end{array}$ & Will be discussed in the following findings \\
\hline
\end{tabular}


Table 3. (Conti)

\begin{tabular}{|c|c|c|c|}
\hline & General Description & Used Strategies & Outcomes \\
\hline $\begin{array}{l}\text { Office building } \\
\text { functioning as a Bank } \\
\text { (B) }\end{array}$ & $\begin{array}{l}\text { - The main garden organiza the building } \\
\text { into a U shape with an open working } \\
\text { space focusad around an oasis of palm } \\
\text { trees and greens. } \\
\text { - The main entrance's atrium includes a } \\
\text { vagetated courtand overlook the main } \\
\text { garden as well. The exterior facades were } \\
\text { designed with highefficiency. } \\
\text { The external facades contains windows' } \\
\text { strips that varies in the dimensions to } \\
\text { make appropriste amount of daylight pass } \\
\text { and to avoid extra hast gaining from the } \\
\text { sun. }\end{array}$ & $\begin{array}{ll}\text { - } & \text { Visual Connection } \\
\text { With Nature. } \\
\text { - } \quad \text { Daylight } \\
\text { interaction. }\end{array}$ & Will be discussed in the following findings \\
\hline
\end{tabular}

\section{Results and discussion}

The research focused on some natural elements integrated in the workplace interior design in office buildings in Egypt which considered for the study in the survey, and took note into account that these elements is not the only factors that may have an impact on the performance of the employees in an interior workplace environment. These elements are: Visual and nonvisual connection with nature, Exposure to water elements, Daylight interaction, Thermal and Airflow Variability, Natural Materials and Natural shapes and forms.

This was conducted in a two-step exploration:

a- Questionnaire sent to occupants.

b- Questionnaire responses analyzed.

In the first step, the survey was sent out to sample of office buildings' occupants. In step two, the combined results of the survey responses were collected then analyzed and findings were presented. The survey was made by the researcher and consisted of natural elements integrated into several series of various conceptual design of an office workplace environment and presented as digital renderings. For example, the strategy of the quality views was presented in the form of (a) floor to ceiling glass curtain wall, (b) clerestory windows, and (c) windows at eye level. Each series of digital renderings was accompanied by a primary question and a secondary question that allowed for explanation and a short-answer response. In step two, the combined results of the survey responses were then analyzed and findings were presented. The survey took in consideration the different seasonal climate change and how it affect daylighting and thermal comfort inside the building.

A sample of 300 participants to participate in the survey was chosen in both buildings. The data also revealed that most of the employees (93\%) believe that the new office buildings' design leads to superior overall performance, also makes a company more competitive. However, the remaining (7\%) of employees didn't believe that the workplace design has any effect on their performance. Which indicates that good workplace design can make a substantial difference in staff performance, and consequently has a positive impact on the corporations' productivity.

The chosen indicate that $(37 \%)$ respondents were females, and the remaining $(63 \%)$ were males. Also $65 \%$ of the sample was under 30 years old, while $25 \%$ aged from $30-40$ years old and the remaining $10 \%$ respondents aged from 40- 60 years old. 
Data was analyzed to identify the factor that has a high effect on employee's performance. Different natural elements are used to indicate which natural elements do employees prefer to be surrounded with as shown in (figure 15).
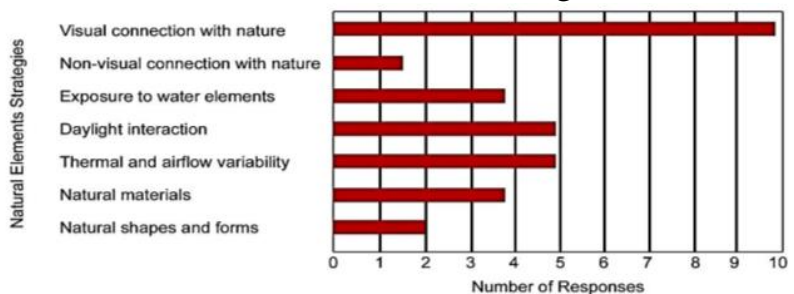

Fig. 15. The mean values of the overall response for each natural element.

Visual connection with nature was chosen as the most contributing factors which affect the performance of employees (32.6\%). This means that presence of nature weather inside the office as greenery spaces or outdoor areas with interface with the employees has great effect on the performance. While natural daylight and thermal and air variability came second $(16 \%)$. Presence of water elements and natural materials came equals in the third rank (12\%). While natural shapes and forms came fourth (6\%) and non-visual connection with nature came at last (5.4\%).

\section{1. Overall responses according to gender}

(Figure 16) shows that female employees are more affected by the surrounding workplace physical environment than the male employees.

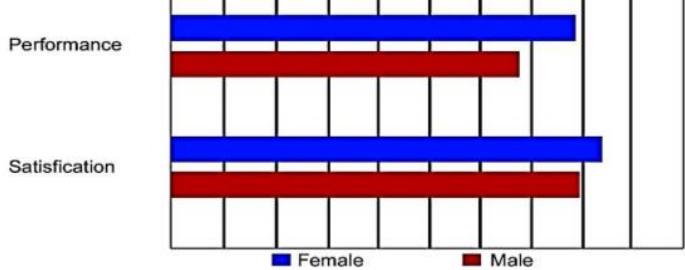

Fig. 16. Level of satisfaction and performance for Males and Females.

The overall response according to the gender is detailed as shown in (table 4) and (table 5). The average ranking indicated that for male and female, visual connection with nature was the most influential factor. Male respondents' results showed that natural daylight has been given the second rate followed by thermal and airflow variability after that came the natural materials. However, exposure to water elements, natural forms and shapes and non-visual connection have been given the lowest significance. Like that, an analysis of female employees' results showed that thermal and airflow comfort is ranked second followed by the exposure to water elements, while natural materials and daylight interaction came next. Like male respondents' non-visual connection to nature and natural forms and shapes came last.

Table 4.

Male employees' responses

\begin{tabular}{|c|c|c|c|c|c|c|c|}
\hline $\begin{array}{c}\text { Natural } \\
\text { Elements } \\
\text { Strategy }\end{array}$ & $\begin{array}{c}\text { Visual } \\
\text { connection } \\
\text { with nature }\end{array}$ & $\begin{array}{c}\text { Non-Visual } \\
\text { Connection } \\
\text { with Nature }\end{array}$ & $\begin{array}{c}\text { Exposure } \\
\text { to Water } \\
\text { elements }\end{array}$ & $\begin{array}{c}\text { Daylight } \\
\text { interaction }\end{array}$ & $\begin{array}{c}\text { Thermal } \\
\text { and Airflow } \\
\text { Variability }\end{array}$ & $\begin{array}{c}\text { Natural } \\
\text { Materials }\end{array}$ & $\begin{array}{c}\text { Natural } \\
\text { shapes } \\
\text { and forms }\end{array}$ \\
\hline Rank & 1 & 7 & 5 & 2 & 3 & 4 & 6 \\
\hline Percentage\% & 29.6 & 6.3 & 9 & 20.1 & 14.8 & 11.6 & 8.4 \\
\hline
\end{tabular}


Table 5.

Female employees' responses

\begin{tabular}{|c|c|c|c|c|c|c|c|}
\hline $\begin{array}{c}\text { Natural } \\
\text { Elements } \\
\text { Strategy }\end{array}$ & $\begin{array}{c}\text { Visual } \\
\text { connection } \\
\text { with nature }\end{array}$ & $\begin{array}{c}\text { Non-Visual } \\
\text { Connection } \\
\text { with Nature }\end{array}$ & $\begin{array}{c}\text { Exposure } \\
\text { to Water } \\
\text { elements }\end{array}$ & $\begin{array}{c}\text { Daylight } \\
\text { interaction }\end{array}$ & $\begin{array}{c}\text { Thermal } \\
\text { and Airflow } \\
\text { Variability }\end{array}$ & $\begin{array}{c}\text { Natural } \\
\text { Materials }\end{array}$ & $\begin{array}{c}\text { Natural } \\
\text { shapes } \\
\text { and forms }\end{array}$ \\
\hline Rank & 1 & 6 & 3 & 5 & 2 & 4 & 7 \\
\hline Percentage\% & 37.8 & 3.7 & 17.1 & 9 & 18 & 12.6 & 1.8 \\
\hline
\end{tabular}

\section{2. Overall responses according to age}

Employees were asked if they can complete their daily tasks easily due to the overall office environment. The analyzed data showed that employees aged from 40-60 years old had been affected the highest by the surrounding workplace physical environment than other employees. Followed by employees aged from 30-40 years old then employees under 30 years old as shown in (figure 17).

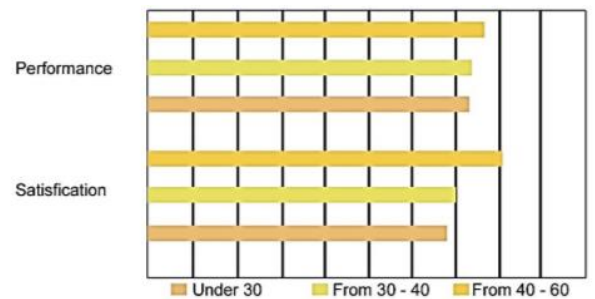

Fig. 17. Level of satisfaction and performance between employees with different ages.

That might be a factor due to the policies of most companies, which provides more care for the top managers in terms of providing better views, indoor greenery, natural daylight, self-control of thermal and air flow variability and natural materials for the furniture. The results also showed that the employees over 40 years old are more concerned about their workplace physical environment more than employees aged below 40 years old.

\section{Conclusion}

Analysis of the collected data revealed that the workplace physical environment has a substantial influence on the employees' performance and productivity. The overall impact of different natural elements showed that visual connection with nature has the most impact on productivity in the opinion of most employees; therefore, it is recommended that we should consider creating as much as we can of visual connectivity with the nature while designing office buildings. The analyzed data also revealed that female employees are more concerned about their workplace physical environment, unlikely, male are less concerned with it. When sorting by ages, the response showed that employees above 40 are more satisfied with their workplace environment.

Utilizing the review of literature, the original research framework, and the data collected from the research survey, the goal was to create a workplace environment that promoted an appropriate relationship between nature and the built environment and one that influenced the psychological, physiological, and spiritual well-being, health and productivity of its users.

In conclusion, most of employees believe that good workplace physical environment can make a difference in their performance, and consequently have a positive impact on the companies' productivity and overall performance. Designers today should expand their knowledge to understand what makes people comfortable and happy at work which will reflect directly on how they perform (efficiency and desirability to work). 


\section{Recommendations and further researches}

The research component was limited in producing valuable quantitative and qualitative data for the use of the integration of specific natural elements and it is effect on employees in the office buildings environment. In addition to that, the original research component was limited to only visual survey. If this study were to be furthered, there are several other natural elements that could be tested in office buildings' design or on another design programs.

It may be beneficial for further studies to the study to have a larger sample size so that the data generated could be more significant in yielding an accurate depiction of integrated natural elements. It would also be beneficial to consider surveying a greater variety of design professionals to gain a better understanding of the perception of the professionals and the impact it may have on the chosen natural elements integration. This research is carried out in office buildings in Egypt and may differ if it was applied in any other part of the world due to the differences in culture backgrounds or any other social or economic factors.

It also may be beneficial to integrate the natural elements into different design programs. These may include residential, educational, and healthcare applications within an urban context. A more widespread inclusion of integrating natural elements in the urban built environment could promote the human-nature connection on a grander scale, enhancing the overall well-being, health and productivity of a much larger population. The literature presented in this study was published between 1960 and 2017. However, still the major focus of the review is 2000 onwards in order to analyze the current state of the art knowledge.

\section{REFERENCES}

[1] Kellert, S.R. \& Wilson, E.O. (Ed.). (1993). The biophilia hypothesis. Washington D.C.: Island Press.

[2] Moore, T., Carter, D. and Slater, A. (2002) Lighting Research and Technology. Wang, D., Federspiel, C. C. and Aren, E. (2005).

[3] Kellert, S. R. (2008). Dimensions, elements, and attributes of biophilic design. In Biophilic design: the theory, science, and practice of bringing buildings to life. Hoboken, N.J.: Wiley.

[4] Kellert, S.F. \& B. Finnegan (2011). Biophilic Design: the Architecture of Life (Film). Bullfrog Films. A short documentary by Stephen R. Kellert and Bill Finnegan, 2011.

[5] Sternberg, E.M. (2009). Healing Spaces. Cambridge: Bleknap Harvard University Press.

[6] Fromm, E. (1964). The Heart of Man. Harper \& Row (NYC). useful links for the book:

[7] Online Site: http://fromm-online.org/en/

[8] Google

Books:

https://books.google.com.eg/books?id=kJ7K XajW6YC\&printsec=frontcover\&dq=the+heart+of + man+erick + fromm\&hl=en\&sa $=X \& v e d=$ 0ahUKEwj72KaWnojgAhUSmbQKHfImDAAQ6AEIKzAA\#v=onepage\&q=the\%20heart\% $20 \mathrm{of} \% 20 \mathrm{man} \% 20 \mathrm{erick} \% 20$ fromm $\& \mathrm{f}=$ false

[9] Wilson, E. O. (1984). Biophilia. Cambridge, Mass.: Harvard University Press.

[10] Sandifer, P.A., Sutton-Grier, A.E., Ward, B.P. (2015). Exploring connections among nature, biodiversity, ecosystem services, and human health and well-being: Opportunities to enhance health and biodiversity conservation.

[11] Browning, W.D. \& J.J. Romm (1994). Greening the Building and the Bottom Line. Rocky Mountain Institute. website: https://www.rmi.org.

[12] van den Berg, A.E., T. Hartig, \& H. Staats (2007). Preference for Nature in Urbanized Societies: Stress, Restoration, and the Pursuit of Sustainability. Journal of Social Issues.

[13] California Energy Commission, Windows and Offices: A Study of Office Worker Performance and Indoor Environment: Technical Report (2003), Oklahoma State University Healthy and Safety Office, You Can Do Something About Eyestrain (2011). 
Ahmed Abd Elghany Morsy, Mahmoud Abdelrahman Moustafa Emam, towards a better .........

[14]Leech, J.A., Nelson, W.C., Burnett, R.T., Aaron, S., Raizenne, M.E., 2002. It's about time: a comparison of canadian and american timeactivity patterns. J. Expo. Anal. Environ. Epidemiol. 12(6):427-32.

[15] Kaplan, R., \& Kaplan, S. (1989). The experience of nature: a psychological perspective. New York: Cambridge University Press.

[16] Kellert, S.R. \& Wilson, E.O. (Ed.). (1993). The biophilia hypothesis. Washington D.C.: Island Press.

[17] Fuller, R.A., K.N. Irvine, P. Devine-Wright, P.H. Warren, \& K.J. Gaston (2007). Psychological Benefits of Green space Increase with Biodiversity.

[18] Stigsdotter, U. A. (2004). A garden at your workplace may reduce stress. Dilani, A (ed.), Design and Health III - Health Promotion through Environmental Design. Stockholm: Research Centre for Design and health.

[19] United States Green Building Council.

[20] Jahncke, H., S. Hygge, N. Halin, A.M. Green, \& K. Dimberg (2011). Open-Plan Office Noise: Cognitive Performance and Restoration. Journal of Environmental Psychology, 31, 373-382.

[21] Koga, K. \& Y. Iwasaki (2013). Psychological and Physiological Effect in Humans of Touching Plant Foliage - Using the Semantic Differential Method and Cerebral Activity as Indicators. Journal of Physiological Anthropology, 32 (1), 7.

[22] Hildebrand, G. (1991). The Wright Space: Pattern \& Meaning in Frank Lloyd Wright's Houses. ournal of Architectural Education, 47(2), 116-117.

[23] Kellert, S.F., J.H. Heerwagen, \& M.L. Mador Eds. (2008). Biophilic Design: The Theory, Science \& Practice of Bringing Buildings to Life. Hoboken, NJ: John Wiley \& Sons.

[24] Heerwagen, J.H. \& G.H. Orians (1993). Humans, Habitats and Aesthetics. In: S.R. Kellert \& R.S. Wilson (Eds.). The Biophilia Hypothesis (138-172). Washington: Island Press.

[25] Alvarsson, J., S. Wiens \& M. Nilsson (2010). Stress Recovery during Exposure to Nature Sound and Environmental Noise. International Journal of Environmental Research and Public Health.

[26] Loftness V. \& M. Snyder (2008). Where Windows Become Doors. Hoboken, NJ: John Wiley \& Sons. (119-131).

[27] Nicklas, M.H. \& Bailey, G.B. (1996). Student Performance in Daylit Schools. Innovative Design. Raleigh, North Carolina. 17(2), 41-61.

[28] William, B., Catherine R., and Brager, Gail (2014). 14 patterns of biophilic design improving health \& well-being in the built environment. Archnet-IJAR, 8, (62-76).

[29] Heerwagen, J.H. (2006). Investing In People: The Social Benefits of Sustainable Design. Rethinking Sustainable Construction. Sarasota, FL. September 2006, (19-22).

[30] Lichtenfeld, S., A.J. Elliot, M.A. Maier, \& R. Pekrun (2012). Fertile Green: Green Facilitates Creative Performance. Personality and Social Psychology Bulletin. University of Munich. 38(6), (784-797).

[31] Tsunetsugu, Y., Y. Miyazaki, \& H. Sato (2007). Physiological Effects in Humans Induced by the Visual Stimulation of Room Interiors with Different Wood Quantities. Journal of Wood Science. 53, (11-16).

[32] van den Berg, A.E., Y. Joye, \& S. de Vries (2007). Health Benefits of Nature. In: L. Steg, A.E. van den Berg, \& J.I.M. de Groot (Eds.), Environmental Psychology: An Introduction (47-56). First Edition. Chichester: Wiley- Blackwell.

[33] Vessel, E., (2012) . New York University Center for Brain Imaging. 14 patterns of biophilic design improving health \& well-being in the built environment. Archnet-IJAR, 2014, 8, (62-76).

[34] Terrapin Bright Green (2016). New York: Terrapin Bright Green llc.

[35] U.C. Berkeley's Center for the Built Environment's occupancy satisfaction survey.

[36] Online site: https://www.cbe.berkeley.edu/research/briefs-survey.htm

[37] Smith, M., Whitelegg, J., Williams, N (1998) "Greening the Built Environment." Earthscan Publications, London.

[38] Mortice, Z., (2016). Nature Does It Better: Biomimicry in Architecture and Engineering. Autodesk newsletter.

[39] Partington R., and Bradbury S., (2017) Better Buildings: Learning from Buildings in Use, Newcastle: RIBA Publishing.

[40] Abbaszadeh, S., Zagreus, L., Lehrer, D. et al. (2006) Occupant satisfaction with indoor environmental quality in green buildings, California Digital Library, University of California. 


\section{نحو آداء أفضل للمباني الإدارية عن طريق دمج العناصر الطبيعية بها}

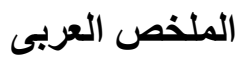

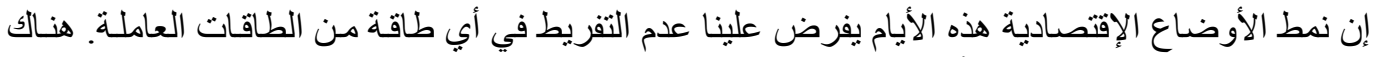

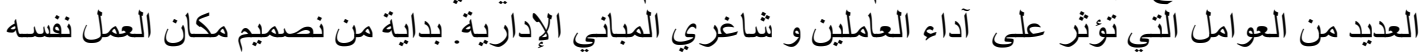

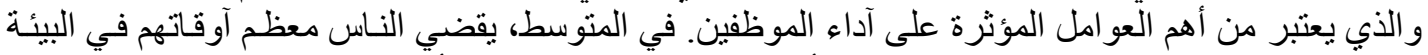

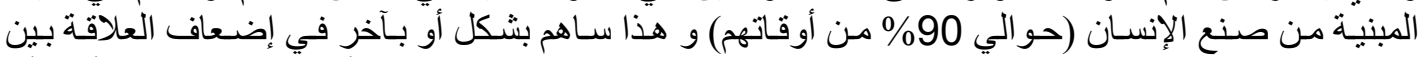

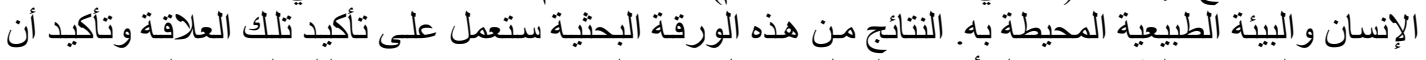

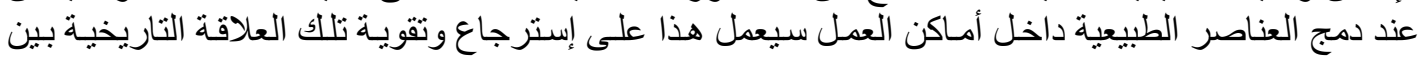

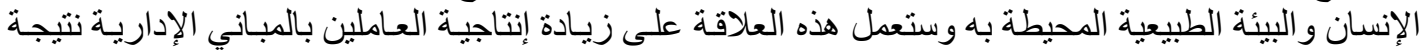
لثعور هم بالإرتياح و الإنسجام.

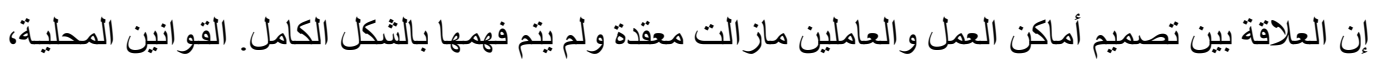

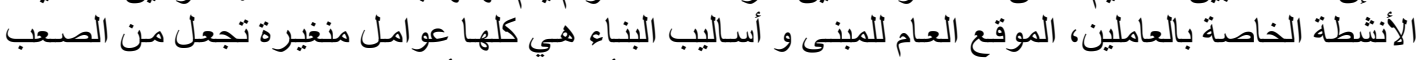

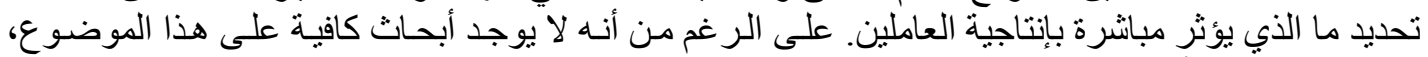

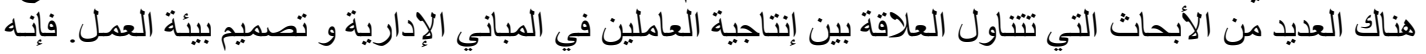

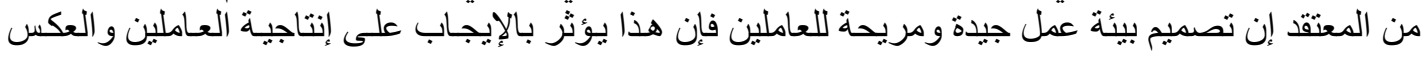

بسبب الزيادة المستمرة في أعداد السكان، فإن التصميم الذي يحي العي العلاقة التاريخية بين الإنسان و البيئة

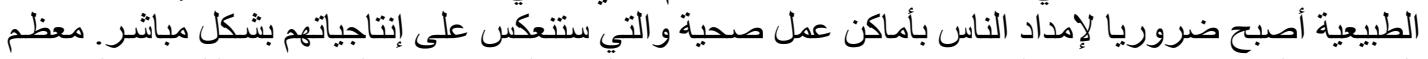

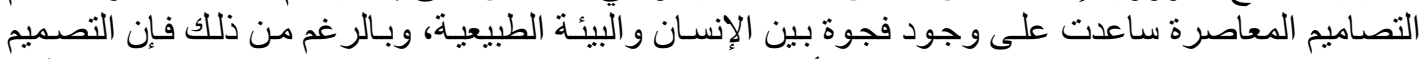

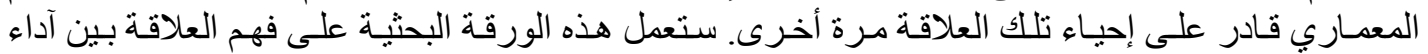
العاملين بالمباني الإدارية و بيئة العمل المحيطة بهم عند دمج العناصر الطبيعية بها. 